\title{
The Essential Dimensions of Health According to the Maqasid al-Shari'ah Frameworks of Abu Ishaq al-Shatibi and Jamal-al-Din-'Atiyah
}

\author{
Aasim I. Padela ${ }^{1,2,3}$ \\ ${ }^{1}$ Associate Professor of Emergency Medicine, Department of Medicine, The University of Chicago ${ }^{2}$ Director \\ of the Initiative on Islam and Medicine, Program on Medicine and Religion, The University of Chicago \\ ${ }^{3}$ Faculty, Maclean Center for Clinical Medical Ethics, The University of Chicago
}

\begin{abstract}
Contemporary Muslim thinkers have shown increasing interest in the higher objectives of Islamic law, maqașid al-shariah for reasons of utility and flexibility. Inductively derived from scriptural source-texts and the inherited legal canon, the maqasd have proven to be useful in interfaith dialogue and in addressing modern contexts because they are rationally accessible and can incorporate knowledge coming from the natural and social sciences as well as the humanities. In this paper, I examine the maqasid for applicability to the healthcare context. Specifically, I will describe the maqașid formulae of Islamic scholars Abu Ishaq al-Shatibi and Jamal-al-Din- Ațiyah (Gamal Eldin Attia) and use them to generate theoretical models of the essential dimensions of human health. During my analyses of these authors' frameworks, I will examine their views on how the maqașid are discovered, and on focus on their discussions regarding the preservation of human life and intellect. I will also compare the relative relevance of their models to modern biomedicine in terms of their "openness" to data coming from the health sciences and in light of contemporary knowledge about the determinants of health.
\end{abstract}

KEY WORDS: Islamic Bioethics, Islamic Law, Philosophy of Medicine, Higher Objectives of Islamic Law, Biomedicine

\section{INTRODUCTION}

Muslim ethical reflection proceeds from multiple different genres within the Islamic intellectual tradition. For example, the cultivation of Godly virtue is the central concern of Islamic sciences related to spirituality, tașawwuf. Similarly, virtuous character formation is the core concern of the Islamic science of etiquette, 'ilm al-ahklāq, and is the focus of the practices prescribed within the $a d a b$ genre. Yet, when examining the moral frameworks of Islam, Islamic law, SharT'ah, and its related sciences are privileged. This paper draws upon one of these sub-fields and genres, the higher objectives of Islamic law, maqasid al-Sharīah, to discuss the essential aspects of human health and well-being.

Recent years have seen a growing interest in the maqasid al-shariah for many reasons. In the aftermath of colonialism and with the subsequent rise of the modern nation, intellectual stagnation continues to pervade institutions of traditional Islamic learning leaving seminarians ill-equipped to address the new social orders stirred by the many isms of the post-colonial and contemporary period: secularism, political authoritarianism, pluralism, globalism, and scientism to name a few.Against this backdrop, many Muslim revivalist projects have set

Aasim I. Padela

Associate Professor of Emergency Medicine, Department of Medicine, The University of Chicago.

Email: apadela@uchicago.edu out to reform the application of Islamic law and its related sciences. The maqasid al-shariahas a subfield of Islamic law has therefore been a site of intense study and debate. This genre of ethico-legal reflection is proposed to offer a corrective for Islamic rulings, figh, and Islamic moral theology (ușūl al-fiqh), the hermeneutical science that undergirds fiqh. This is because the higher objectives of the Lawgiver, maqasid are held to be more deeply rooted in the moral vision of Islam than singular rulings derived from limited scriptural evidences. ${ }^{1 \& 2} 2$ In other words, the higher objectives represent the intents of the Lawgiver and speak to the broader "spirit" of legislation, and thus can they can assist in generating the letter of the law. ${ }^{3}$ Exactly how the maqasid might do so remains an open question. Certainly, the maqasid are believed to allow constructs and data from "outside" the bounds of Islamic scripture to have greater authority in determining the law than traditional ușūl-based methods of generating fiqh. For example, once the preservation of life has been established as a higher objective of Islamic law, data from the health sciences can help delineate how we might best do so. As such, renewers and reformers champion research into the development of maqasid, thereby seeking a bridge by which the inherited Islamic ethico-legal canon can extend its reach to modern contexts. Similarly some scholars assert that since the maqasid represent by definition, the telos of Islamic law, the genre can undergird a broad philosophy of Islamic law and also provide theological constructs that can be applied in Islamic ethico-legal reasoning. ${ }^{4}$ Finally, while the primary maqasid are inducted from scripture, they are 
rationally accessible and therefore do not require religious supports in debates about ethics, law and policy. This character also makes the maqasid an incredibly useful tools by which Islamic values can be advocated for in diverse and plural settings.

Consequently, maqasid-based approaches to Islamic law and ethics abound, and this paper builds upon these efforts by drawing upon the maqasid to build and identify the essential (minimal) dimensions of human health. In order to do so, I will examine writings of two maqasid theoreticians: Abū Ishāq alshatibiand Jamāl-al-Dīn- Ațīyah (Gamal Eldin Attia). al-shatibi(d. $790 \mathrm{AH} / 1388 \mathrm{CE})$, a $14^{\text {th }}$ century Sunni legal theorist and scholar of the Maliki school of law, is widely considered the "father" of the sciences of maqasid al-Sharīah. He was among the first, if not the first scholar, to argue that the maqasid are fundamental to Islamic jurisprudence and form the basis for every Islamic ruling.

He was the first to lay out a comprehensive theory of maqasid in his treatise, al-Muwafaqqāt fi ușūl alshariah(The Reconciliation of the Fundamentals of Islamic Law). ${ }^{1}$ \& 4 Attia (b. 1928 CE) is a contemporary Islamic legal theorist who holds a doctoral degree in law from the University of Geneva and held academic posts in Islamic law at universities and Muslim think-tanks. ${ }^{3} \mathrm{He}$ has written an extensive treatise, Nahwa taf'il maqas̄aid alshariah (Towards Realization of the Higher Intents of Islamic Law: maqasid al-Sharīah; A Functional Approach) which revises and extends the maqasid al-Shariah to integrate contemporary human, social and physical sciences into maqasid frameworks. ${ }^{3}$ I chose these authors and works, one classical and the other contemporary, because they are accessible both in Arabic and in translation. In addition, the concepts and theories are relatively well-fleshed out by the authors, and because they provide windows (bookends in a certain sense) into the developing theory and specification of the maqasid. In order to identify the essential components of health, I will focus primarily on discussions pertaining to the preservation of life, hifz an-nafs, as a higher objective of Islamic law, and then secondarily upon the objective related to the preservation of the intellect and/or mind. I readily acknowledge that my purposive methods may introduce limitations to this study. For example, restricting my sources to two authors and primarily to two texts written by these theorists may overlook developments in both the theory and specification of maqasid al-shariahthat might be found elsewhere, and relying upon on a few particular higher objectives may miss discussions about health-related aims of other higher objectives.

This monograph will proceed in the following manner. In the next section, I will describe what the maqasid al-shariah represent and how they are/were determined. The following two sections will focus upon the maqasid formulae of Abū Ishāq al-shatibi and Gamal Eldin Attia. I will begin each section by discussing the respective scholars' classification of maqasid as well as their dimensionality, and next proceed to enumerate their respective views on hifz an-nafs and preservation of the mind/intellect and its constituents. After these discussions, I will discuss models for the essential dimensions of health as gleaned from the two writers and for their relevance to the modern healthcare context. Finally, I will close by commenting on future directions and limitations of research at the intersection of maqasid al-shariah and contemporary biomedicine.

\section{Brief overview of Maqasid al-Sharī'ah Terminology}

Since Islam is a scriptural tradition and Islamic legal theories utilize a variety of formal methods to build out moral law from these limited scriptural sourcetexts, understanding divine intent in issuing commands and prohibitions is a central concern for moral theologians and legal theorists. The maqasid al-shariah represent the overarching aims (also referred to as the higher objectives or intents) of Islamic law. The term is also used to refer to a specific genre of Islamic ethico-legal writing that pertains to understanding, explicating, developing and applying theories of Islamic jurisprudence and ethics from maqasid.

There are several legal concepts that the term maqasid maps onto, and the different ways in which jurists use the terms can be confusing. These related terms are hikmah, 'illah, and mașlahah. While a detailed explanation of these terms is beyond the scope of this paper, particularly since the different schools of law and several authoritative legal theorists have slightly different definitions of these terms, I will briefly describe how these terms relate to maqasid. The maqasid alshariah(sing. maqșid) refer to the "purpose or goal" of Islamic law in its totality and "the underlying reasons which the Lawgiver has placed within each of its rulings." ${ }^{1}$ When considering the positive purpose of legislation in the end-result of action, the term, hikmah, can be used synonymously with maqasid. ${ }^{1 \text { \& } 5}$ Hikmah is used by legal theorists to indicate the wise purpose of the Lawgiver behind a given ruling. By convention, jurists often use the term hikmah when discussing God and maqasid when discussing matters of law. ${ }^{5}$ The overarching purpose of Islamic law is to serve human interests (in this world and the hereafter) and as such to bring about benefit and deflect harm. ${ }^{1}$

The notion of servicing human interests brings the maqasid into connection with the construct of mașlahah. The 11th-12th century jurist-theologian Imam al-Ghazali is often credited with being the first Islamic scholar to map out the mașlahah construct and he connects the two terms. According 
to al-Ghazali "what we mean by interests (mașalih) are those interests that conform specifically to the objectives of Islamic law (maqasid)."6 Although one must bear in mind that while masalih (plural form of masalahah) and maqasid are "parallel concepts and basically look at the same values." ${ }^{5}$ mașlahah as a legal construct has different types and authoritative validity in generating law within the Islamic schools. Therefore, using the terms interchangeably is fraught with complications that non-specialists should avoid.

Finally in Islamic legal terminology the term 'ilal (singular 'illah) is also closely related to maqasid. 'illah is used in three ways by theologians and jurists: (i) to indicate the 'benefit' or harm resulting from an action, (ii) the achievement of benefit or the prevention of harm resulting from the legislation of a given ruling, and (iii) the observable, identifiable condition or situation on the basis of which a given ruing is legislated for human beings' benefit'."1 From these usages, one can easily see that the terms hikmah and maqasid map on to the first two connotations of 'illah, and sometimes writers use the maqasid for the third. ${ }^{4}$ Yet, when undertaking Islamic analogical legal reasoning, qiyas, the term 'illah is used to refer to observable, identifiable, triggering conditions or situations that are the cause for a particular legal ruling. ${ }^{1}$ \& 5 This condition, which was the rationale for the original judgement, if found in a new context might allow for extending the ruling to the new context. The term 'illah is best used for this technical purpose. Finally the term maqasid alshariah conventionally refers to the overall rationale, or comprehensive and general objectives of the law (al-maqasid al-'ammah), and not the singular and particular "illah behind a specific rule which explains why " "illah is very close to maqasid" but not exactly the same. ${ }^{5}$

An example that is often used to illustrate the conventional distinctions in terminology is the ruling that one can shorten prayers on a journey. Here the 'illah is being on a journey, the hikmah is removal of hardship, the mașlahah is facilitation of worship, and the maqsid is preservation of religion. Hence the 'illah which is cause and trigger for the ruling stands closer to the moral agent and somewhat apart from the wisdom of the Lawgiver which is closely related to the human benefit to be secured, while the higher objective is more general.

\section{How are the Maqasid identified?}

Imam al-Shataibi, the father of the maqasid alshariahtheory, declared the maqasid to be the "fundamentals of religion, basic rules of the revealed law, and universals of belief." 4 \&5 By alluding to them in this way, al-shatibiasserted the maqasid to be the bedrock upon which all of Islamic law is built. Lest the foundations be shaky, alShatabi's had to prove that the maqasid can be certainly known and are definitive (qat'̄i). Al-
Shataibi's genius was to assert that a comprehensive inductive reading of the scriptural sources of Islam, the Qur'an and Sunnah, was sufficient to definitively arrive at the higher objectives of the Law. This method of induction is central to alShataibi's theory, and to all maqasidi approaches by extension for "the universals of Islamic Law are not based on a single piece of evidence, but on many such pieces which, when taken together, convey a single message which is thereby invested with complete certitude." ${ }^{1}$ al-shatibi notes that his theorization was based on a reading of " 'all inclusive references rather than limiting [himself] to isolated particulars, demonstrating the textual and rational foundations of [Islamic law] to the extent that (he) was enabled to elucidate' " the maqasid. ${ }^{1}$ It is on the basis of an inductive reading of scripture that al-shatibi surmises that Islamic law seeks to serve human interests, and by which he divides the maqasid into three categories (essential, necessary, and enhancing), and by which he identifies five essential higher objectives of Islamic law (to be discussed below).

While induction is the principal method by which the overall maqasid are to be discovered, at least according to al-Shataibi, he does refer to other means for discovering maqasid. Illustratively in the concluding section of the Book of Maqasid within alMuwafaqqāt, al-shatibi states that the objectives of the Lawgiver are discerned (i) by looking for specific, explicit, univocal commands and prohibitions wherein the text states the objective, (ii) by discovering the rationale ('ilal) that underlie commands and prohibitions utilizing established conventions of Islamic moral theology (ușūl al-fiqh), (iii) by recognizing that there are primary and secondary objectives that undergird the Lawgiver's commands of which the primary are usually explicit and the secondary may be inferred. The inferred secondary objectives whenever they strengthen, reinforce and support the primary objectives are considered to be valid intentions of the Lawgiver although these secondary objectives are rationally derived. ${ }^{1}$ The final and fourth means of discovering the maqasid is using human reasoning. This latter method is allowed when the Lawgiver is silent about a matter and no textual evidence exists to substantiate or negate a specific human interest. For al-Shataibi, a Maliki legal theorist, this method equates to using the Maliki methodological device of mașlahah mursalah.

While the method of using "pure" human reason represented mașlahah mursalah for al-Shataibi, for the preeminent classical Shafi jurist al-Juwayni using human reason to "discover" maqasid relied on istidlāl, a reasoning technique considered valid by the Shafi school even if the objective (human interest) cannot be traced to a text. In summary, the argument is that since the Lawgiver established laws that brought about benefit for humankind in this world and the next, using human reason to judge the benefits and harms of this world allows 
one to posit the intents of the Lawgiver to a reasonable degree. Accordingly, some jurists simply referred to this final method as using the human intellect ('aql). ${ }^{5}$ It is important to recognize that as we proceed from the first to the fourth method, a greater level of theorization and a greater role for human reason is posited. The first method remains close to the text, the second subsumes the usul alfiqh-governed rules for ta'lil, the third uses inference to discover a secondary objective, and the forth utilizes human reason regarding benefits and harms to judge objectives of the Lawgiver when explicit texts are silent. The operating space given to reason to go "beyond" the text is a critical aspect of maqasidi theories that allow Islamic law to adapt to changing times and contexts and generate new laws.

Finally it is also worth noting that, for al-Shatibi, these four methods largely come into play when trying to discover specific objectives or rationale behind (or for) laws. In other words, these methods operate at a "lower" level than induction, for induction is the means by which the overarching, essential, higher objectives are discerned. So for him an explicit text might indicate that the Lawgiver intends for the preservation of life, however elevating the preservation of life to be among the higher objectives of Islamic law, the overall maqasid requires a comprehensive inductive reading of the Qur'an and Sunnah.

Maqasid theorists following al-Shataibi, mostly affirmed al-Shatibìs methods although they rearranged his schema and circumscribed or expanded the scope of reason. ${ }^{3}$ For example, Attia states that "there is no conflict between a basic reliance on the methods outlined by al-shatibi for arriving at maqasid al-Shari'ah, and the addition of a supplementary methods in the event that the existing methods prove insufficient." ${ }^{3}$ For him, this supplemental method is a reason-based approach to discerning maqasid. Attia further states that all of the methods are complementary but can operate independently. Finally Attia outlines that when using human reason to induct, infer, or originate maqasid, the proposed maqașid are valid only when (i) there is no definitive scriptural source that already points to the maqșid confirming it, (ii) the maqșid must not conflict with a definitive scriptural text or another maqșid derived from such texts, (iii) if there is apparent conflict between a proposed maqșid and scriptural sources or maqasid derived therefrom resolution is demanded through recourse to established hermetical rules, and (iv) the proposed maqșid must emerge (loosely) from reliably transmitted scriptural sources with clear self-evident meanings, and be consistent across time, person, place and context, and constantly applicable. ${ }^{3}$ It bears mention that there is a certain level of apparent circular logic at play in this rubric when one uses reason to discern human interests and elevate them to the level of a higher objective of Islamic law. Such a usage of reason would be independent of scripture or supplemental to scripture, in other words at best it would be "informed" by scripture but not confined to it. Accordingly, the criteria laid out for validating such maqasid cannot use scripture as validating authority. In my view some of the ambiguity emerges from the strategic need to obtain "buy-in" from scholars who desire to remain close to the texts and within the bounds of inherited ușūl paradigms. Another reason may be that theoreticians like Attia and al-shatibifocused on broad guidelines and laid out constructs and tools to build theory. Refinement will require application and until these schemas are widely applied and tested the various maqasidi approaches remain in the formation phase.

\section{Al-Shatibirs Theory of Maqasid and the Preservation of Life}

\section{Categorizing the Maqasid and Identifying the Essential Ones}

As briefly mentioned above, al-shatibi breaks down the maqasid into three categories according to levels of importance. He derives this schema through induction and labels the categories as darūrī, hājī, and tahsīn̄i. Darūrī or essential maqasid "seek to establish interests of the $d \bar{l} n$ [literally religion but connotes the hereafter in this usage], and the dunya [this world]...their absence leads to corruption and trials as well as loss of life," and consequently leads to "loss of success and blessings" in the hereafter. ${ }^{9}$ The $h \bar{A} j \bar{l}$ or necessary maqasid are those needed to attain facility and remove obstacles for without them humans face difficulty and hardship.The tahsinnī or enhancing objectives represent acquiring the "good things" and avoiding the "deceptive" things, such that the actions and practices are ornamented and perfected. ${ }^{9}$ The relationship between the three categories is that the $h \bar{A} j \bar{l}$ supplement the darūrī, while the tahsinni complement the hājī. Furthermore, while trying to secure the objectives a hierarchal order needs to be maintained such that in securing the $h \bar{A} j \bar{l}$ the darūrī must not be compromised. In other words, the darūrī are the basis for the hajī and tahsīnī, for "if the suspension of the darūri is assumed the other two will stand suspended in absolute terms"'. It also worth noting that the maqasid can be categorized in several different ways: in terms of scope- general ('āmmah), particular (khāșșah) or partial (juz'̄̄) or in terms of certainty- definitive (qaț'ī) or speculative (zannī). Indeed al-shatibiuses these other terms as necessary to explain the inner working of his theory, however for our purposes the schema as related to level of importance is most pertinent and represents one of al-Shataibìs novel contributions to the field of maqasid.

Before moving to case examples, identifying the essential maqasid is necessary. Al-shatibiidentifies 
five essential, darūrī, maqasid. These are the preservation of religion (dIn), human life (nafs), progeny (nașl), material wealth (māl), and intellect ('aql). These five interests are the chief objectives that all Islamic injunctions are (should be) tied to. Al-shatibiarrives at these maqasid by means of induction, first looking at the commandments contained within the Meccan parts of the Qur'an which according to him contain the universal values of the Law and then examining the Medinan verses which describe the particulars. He similarly observes that the commandments and valuations contained within the Prophetic Sunnah are explanations of the Qur'an, and accordingly all of Islamic law proceeds outwards from these two revelatory sources. ${ }^{1}$ While al-Ghazali originally set out the maqasid in the format of the "protection (hifz) of x," alshatibiutilizes the same formulation and states that preservation entails a dual responsibility establishing the existence of the interest ( $\left.i b q \bar{A}^{\prime}\right)$ and defending against its negation (hifz). Accordingly, hifz carries the multi-faceted obligations of preservation, maintenance and protection of the interest at hand through Islamic law. As alshatibiscrutinizes the four domains of Islamic legislation- ibadĀt (worship), mu'amalāt (human relations and transactions), 'adāt (human practices), and jinĀyĀt (criminal law)- he finds that one or another of the five essential maqasid predominate within the ordinances related to a domain. Preservation of religion is at the core of worship related injunctions, while preservation of life and of intellect is central to Islamic laws pertaining to human practices. Mu'amalāt-related injunctions seek to preserve material wealth and progeny, while criminal law focuses on protecting all of the five essential maqasid through punitive and deterrent measures. ${ }^{9}$

Although the five essentials together comprise an interdependent unit, al-shatibi states that if religion is not preserved then the "affairs of the next world cannot survive" and the purpose of creation is thwarted. Yet if life is lost then there is no moral subject, and if reason is missing religious belief will become non-existent. Similarly, if the capacity for progeny is totally lost then the survival of life is atrisk and without preservation of material wealth "life cannot be maintained." Consequently, the preservation of material wealth and (capacity for progeny) serve the preservation of life, while the preservation of the intellect and of life are subordinate to the ultimate good- religion. While alshatibi considers preservation of religion to be the foremost higher objective of Islamic law, others hold preservation of life to be the highest objective because without life religion the otherworldly interests of religion cannot be sought. ${ }^{3}$ This debate is beyond the scope of this present paper but an area that requires exploration for developing an Islamic philosophy of healthcare so that spiritual and physical health needs can be appropriately understood and provided for. After religion, alshatibi holds that preservation of life is the most important maqașid. ${ }^{3}$ With respect the order of priority among the preservation of progeny (nașl), material wealth $(m \bar{A} l)$, and intellect ('aql), Attia notes that al-shatibidoes not maintain a consistent order, while other commentators see a hierarchy in the order as presented. ${ }^{1 \text { \& } 3}$ This debate does not frustrate our purposes since I intend to examine only the perseveration of life and of intellect in detail.

Examples of maqasid that are from the hajī category are allowances that remove "difficulty and hardship" such as exemptions from worship during travel and illness which support the essential objective of preserving religion. The fact that the Qur'an provides the option of shortening prayers and making up obligatory fasts after travel has been completed illustrate that facilitation and removal of hardship is a means to preserve the higher objective of religion. In related fashion, the removal of impurities from one's clothing or the covering of one's private parts whilst praying are Islamic ethicolegal injunctions that adorn one's worship and complement it. These acts, in turn, reflect tahsinī objectives of the Law, as they enhance worship which in demanded by the darūri objective of preserving religion.

In addition to thinking about a hierarchical order of priority, another way to envision the relationship between the darūrī, hajī and tahsīnī objectives is by thinking of them as concentric circles with the dārurī as the centermost circle and the tahsinni as the outermost. In this way the tahsīnī and hajī protect the darurī objectives and even if not met (or are lost), the darÜri can be maintained. ${ }^{7 \notin 9}$ For example the maqasid of preservation of religion through establishing prayer can be met even if one must pray with clothes that have a minor amount of impurities on them and chooses not to take the facilitation of shortening prayer during travel.

\section{The Preservation of Life and of Intellect and their Essential (Darūrī) Aspects}

As noted above, the preservation of life (hifz annafs) involves establishing the conditions for life and protecting against its termination in the universal sense. Al-shatibisets out three ways in which this objective is actualized by the Islamic law. First, the legitimacy of procreation is established thereby setting the foundations for life to be "produced." Second, preserving life equates to the maintenance of life, and the provision of food and drink becomes part of the maqșid. The third way the preservation of life is achieved, according to al-Shataibi, is via the provision of clothing and shelter which ensures human survival from external threats. ${ }^{1}$ al-shatibi claims these three means (some consider the three to actually be two means as they join the provision of food, drink, clothing and shelter together as part of protecting life) to be contained within the Qur'an and their elucidation to 
be found in the Sunnah. Further expounding on these means al-shatibi notes that the ensuring one's children enter into valid marriages and know the rules and means of divorce, and are protected from sexual misconduct is subsumed within establishing life, while ensuring one's children do eat harmful or lethal items is part of maintaining life. These acts thereby extend the universal aspects of the preservation of life to the family level. Hifz an-nafs also involves criminalizing the taking of life as the Qur'an eloquently states regarding the law of retribution (capital punishment after homicide) "for in [the law of] just retribution (qișās) 0 you who are endowed with insight, there is life for you so that you might remain conscious of God (2:179)." ${ }^{8}$ The essential aspect of the hifz al-'aql involves refraining from intoxicants as evidenced in the Qur'anic prohibition of drinking and of prayer while intoxicated.

\section{Attia's Theory of Maqasid and the Preservation of Life}

\section{Categorizing and Identifying the Maqasid}

Gamal Eldin Attia amends and builds upon alShataibi’s framework in several ways. First he asserts that the categories of darurī, hajī, and tahsīnī (essential, necessary and enhancing) pertain to the means (was'̄'il) by which a particular objective is attained and not the maqasid themselves. In his view the maqasid constitute a unit with the darūri representing the minimal level of what is required to preserve that interest. For example, like al-Shataibi, he considers the provision of food to be a core element of the preservation of human life. When one obtains just enough food to stay alive the darürī threshold of what is demanded by the preservation of life has been met. The provision of a balanced and appetizing diet represents the necessary (haji) benchmark for it removes hardship and facilitates life, while elegant food presentation and refined table etiquette fall under the category of enhancements as they beautify and perfect the means (e.g. food provision) by which protection of life takes place. ${ }^{3}$ Attia finds support for his revision in the writings of the al-'Izz al-Ḍin ibn 'Abd al-Salām, a master Shafi juristtheologian who preceded al-Shataibi. ${ }^{3}$

If we subscribe to Attia's view and shift our gaze from the act to instead on the acted upon a correspondence relationship exists that may bring his revision into close alignment with al-Shataibirs positions. Considering once again the provision of food as part of the maqasid of protection of life, one can imagine that if a person only eats enough food to stave off death that their resulting quality of life (or in other words the condition of their living) is likely to be worse off than an individual who eats nutritionally-balanced meals. And in turn, eating aesthetically pleasing food with appropriate etiquette might, in intangible ways, engender a higher quality of life than not doing so. Hence the differential quality (or condition) of life that results from pursuing the darurī, hajīi, and tahsin̄ī means to protect life is correlated with the means of achieving them.

In al-Shatibi's view the maqasid are classified into darurī, hajī, and tahnsin̄ī, and the preservation of life falls within the essential, darurī, category. However, the hajī and tahsīnī objectives seek to support, supplement, complement and protect the essential objective. More specifically, the haji objectives aim to facilitate and remove hardships, while the tahsinni adorn and beautify actions. With respect to the essential objective of preserving life one could argue than that the Qur'anic command to eat of the pure and good things $(5: 88)$ reflects a haji objective that supports the preservation of life, while following the Prophetic directive to partake of what is nearer on one's plate represent tahsīnī objectives as they instruct about etiquette and thereby beautify the necessary act of eating, while eating in turn facilitates the essential objective of protecting life. Accordingly, the Lawgiver's darūrī aim is to preserve life which demands the provision of enough food that humanity survives, the haji aim that supplements this darūrī objective is to facilitate the flourishing of life that results from eating "the good and pure," and the tahsinni objective is adorn life with aesthetics in food production, delivery and consumption. Here too we recognize variances in quality-of-life such that this schema appears similar to the quality-of-life framework that emerges from Attia's categorization, even though for al-shatibiit is the maqasid that are split into the three domains of essential, necessary and enhancing and not the means.

In addition to relating the categories of darurī, hajī, and tahsīnī to means, Attia also broadens alShataibì's schema to add 2 additional categories. The first he places "under" darūrī and calls it "that which falls short of essential ( $m \bar{A} d \bar{U}$ al-darūrī)" and the second he places "above" tahsīni naming it that which goes beyond mere enhancements ( $m \bar{A}$ warā' al-tahsīnī). These categories are important to Attia because they represent situations that demand remedy. In other words, a means that is subessential to the preservation of life suggests that if instituted it would not be sufficient to reach the end-goal and thus Islamic law must provide a corrective. Similarly, a means that goes beyond enhancing life suggests harmful excess and Islamic law must provide a remedy. Attia calls for greater study into the means that fall into these two categories.

With respect to identifying whether a specific means falls within the aforementioned classification schema, Attia notes that the first recourse is to 
search for a specific and explicit scriptural source that discusses the import of a particular means in terms of the benefit and harms it carries. The greatest benefits accrued or harms averted belong to the darūri category and the most minor to the tahsīnī means. Failing a scriptural source, conventions of analogical reasoning (qiyĀs) should be utilized or a scholarly consensus sought ('ijma). This methodology mirrors standard ușūl al-figh practices. However when these methods do not provide answers about where means to accomplish the maqasid lie, Attia proposes recourse to an "objective criterion" where the degree of benefits and harms associated with the means be assessed. Wherever significant benefit is obtained or harm is removed via a particular means, that means belongs to the darūrī category. Accordingly minor benefits or removal of harms place a means into the tahsinni category, with haji means representing the category of means that fall in between. ${ }^{3}$ It is important to note that this weighing rubric enables Attia's theory to be malleable because the means can change from one category into another based on context and in light of empirical, social scientific, and other data that provide insight into how well different policies and methods achieve the objective.

Attia lays out twenty-four essential maqasid that pertain to four areas or levels of human existence: (i) the individual, (ii) the family, (iii) the Muslim community (ummah) level, and (iv) the level of humanity in general. Although he suggests that there may be five categories for means, he largely adheres to the darūrī, hajī, and tahșinnī classification schema when discussing the preservation of each of the maqasid. In what follows I will briefly catalogue the maqasid within each level but will primarily focus on describing the amendments he makes at the individual maqasid level since these maqasid are the most comparable to al-Shataibīs darūri objectives. Furthermore, in detailing these maqasid I will describe only the darūrī means to secure them as these again are immediately comparable to al-Shatribìs schema.

At the level of the individual there are five maqasid: the preservation of human life, considerations for the mind, the preservation of personal piety, the preservation of honor and the preservation of material wealth. While these maqasid resemble the 5 darūrī objectives identified by al-Shataibī, Attia makes several modifications. First he elevates the preservation of human life to be the foremost objective and also expands upon what it requires (to be discussed in detail in the next section). He also reformulates the preservation of intellect ('aql) to consideration of the mind and moves it to the second position. Consideration of the mind expands beyond the traditional view of preserving the intellect to require developing intellectual capacities and utilizing the mind in "intellectual acts of worship" as darūri. ${ }^{3}$ Developing the mind requires delivering scientific education, building academies and otherwise nourishing and equipping the rational faculties of individuals. With respect to the means of preserving the mind, Attia concurs with the traditional view that it requires staying away from intoxicants, but also adds that it requires "eschewing behaviors that would impede the mind's functions or create mental confusion," and "avoiding media and cultural outlets which engage in brainwashing operations." 3 The maqașid of consideration for the mind via intellectual acts of worship refers to reflection and contemplation of God's word, acquiring religious knowledge, as well as performing ritual meditations. Again these are the essential means by which the objective of consideration of mind is met. Attia refashions the preservation of religion into the preservation of personal piety and lowers its rank order to third for "it is necessary first to preserve human life, which is the basis for all human action, then the mind, which is the basis for our being held accountable before God's law"3 prior to preserving personal piety. The darūrī means for preserving personal piety are establishing and strengthening religious doctrines, performing the obligatory acts of worship and obedience, and focusing on Islamic moral formation. Taking the lead from scholars such as alQarafi, al-Tufi and others Attia reintroduces the preservation of honor into the maqasid. He considers honor to refer to "anything related to human dignity" as well as one's reputation and "sanctity of one's private life." 3 This broad definition is more expansive than the traditional notion of preserving honor as related to one's sexual reputation and heritage. The darūrī means to secure this interest include preventing people from committing slander and making false accusations (through penal injunctions). Attia considers the preservation of material wealth to be of the lowest priority among the maqasid at the individual level. He notes that the preservation of individual material wealth has the social function of providing for one's livelihood and for populating and developing the earth and thus serves the preservation of life. Attia does not expound in details the darūrī means for securing this objective, rather he refers the reader to the Islamic laws of finance, contracts, ownership and the like and the punishments allotted for theft and other such actions as integral means for achieving the goal of preservation of individual material wealth.

While it is beyond the scope of this paper, for completeness sake I would like to enumerate the maqasid pertaining to the family, ummah and general humanity according to Attia. At the family level he suggests that the maqasid are seven: (i) ordering relations between the sexes, (ii) preserving progeny, (iii) achieving harmony, affection and compassion, (iv) preserving family lineage, (v) preserving personal piety within the family, (vi) ordering the institutional aspect of the family, and (vii) ordering the financial aspect of the family. At the Muslim community level there are seven maqasid as well: (i) the institutional organization of the ummah, (ii) maintenance of security, (iii) the 
establishment of justice, (iv) the preservation of religion and morals, ( $v$ ) the promotion of cooperation, solidarity and shared responsibility, (vi) the dissemination of knowledge and the preservation of reason, and (vii) the development and population of the earth and the preservation of the ummah's wealth. Finally, at the broader humanity level, Attia isolates 5 maqasid: (i) promoting mutual understanding, cooperation and integration, (ii) realizing human vicegerency on earth, (iii) achieving world peace based on justice, (iv) promoting international protections for human rights, and (v) disseminating the Islamic message.

The Essential (Darūrī) Means to Achieve the Maqasid of Preservation of Human Life and the

Consideration of the Mind

Attia's equates his vision for the preservation of human life at the individual level to "what is referred to in the law as the right to life, or the sanctity of the body." (Attia 2007, 119) The first category of essential means for the preservation of human life relate to preventing bodily harm and include instituting legal penalties for the taking of life and injury to the body, as well as the prohibition of suicide. He further recognizes the Islamic injunctions concerning blood money (diya') as essential deterrents for murder and bodily harm. The second category of darūri means relate to the maintenance of life. Hence he considers the provision of food and drink, as well as clothing and shelter as essential to securing human life. He also indicates that protecting against "mortal dangers" such as fire, drowning, car accidents and the like are darūrī means. It is particularly significant for our purposes that Attia considers aspects of healthcare to be an essential means for the preservation of life. He states that the "protection against infectious diseases" and the "provision of treatment for those afflicted by illness or accidents," as well as protections against "radiation" are all essential to preserving human life. Indeed he reasons that the "protection of certain parts of the body from harm or damage" is required because "damage to them would lead to the near inability to benefit from the life one has."(Attia 2007, 118)

The essential means for achieving the objective of consideration of the mind have been noted above. Namely this objective demands (i) development of the mind through scientific education, building of academies and institutions that support learning and instruction, (ii) preservation of the mind via refraining from intoxicants and untoward cultural influences, and (iii) utilization of the mind through acts of intellectual worship.

Comparing al-Shataibirs and Attia's Visions for the Essential Aspects of Human Health and Flourishing

The essential elements of the maqasid of hifz annafs (preservation of human life) and of preservation of the intellect/consideration of the mind as outlined by al-shatibi and Attia appear quite similar. Both assert that the provision of food, drink, clothing and shelter are essential for human survival and thus are incorporated into the Lawgiver's objective to preserve life. Al-shatibi appropriately considers procreation key to establishing life and thus considers the Islamic laws defining licit marriages as essential elements for the preservation of life, while Attia appears to neglect these details in his means to preserve life. However Attia incorporates the provision of security as essential means to preserve life as without security, the taking of life might become rampant and a universal threat. Although al-shatibi does not mention the provision of security, he does note that penal measures to prevent rampant murder are necessary to preserve human life, and he argues that the provision of shelter is necessary to protect life from external threats.

As we theorize about the essential aspects of human health from the respective constructions of the higher objectives, Attia's theory appears more fertile for considering healthcare to be essential. Attia mentions protection against infectious disease and providing healthcare to combat illness as among the essential means to preserve life. These elements are "mortal dangers" placing the existence of life at-risk and must be averted. Once life exists then it must be nourished and hence the provision of food and drink is darūrī. Once a state of health is established that is free from mortal diseases and not starving, then physical integrity is prioritized. Indeed physical integrity appears to be at the core of human health according to Attia's maqasid framework. Attia mentions protection from radiation exposure and trauma as darūri instruments for the preservation of human life. He also makes a generic reference to preventing organ injury and bodily harm and the provision of shelter. Another element of health can be gleaned from looking from Attia's framework is mental health. Within the objective of consideration of the mind, he details that the mind is preserved through avoiding brain-washing and intoxicants. Since the objective of consideration of mind is subsidiary to the preservation of life, preserving the faculty of reason appears to also be an essential aspect of health but comes second to physical integrity and the prevention of mortal injuries and starvation. Converting these notions into a mental image, one can visualize a person who has the essential aspects of health to be a minimally-nourished, clothed person free from the drug addiction and mind control, residing in a dwelling within a community safe from murder and assault.

Al-Shatibi's framework offers a slightly different vision. For him, life is established by legislating the procreative capacity of the human, sustained through sufficient food and drink, and secured by the provision of clothing and shelter. Mapping these onto aspects of health, one could argue that reproductive health is central to al-Shatibi's theory 
for if humankind lost the capacity to procreate within the bounds of Islamic marriage, then life in a universal sense would be at-risk. Thus supporting the reproductive capacities might be deemed darūrī. Preventing starvation ("ensuring survival from within") correlates with physical health, and the prevention of bodily harm through the provision of clothing and shelter complete the essential aspects of the maqșid as they secure one against external threats to life. According to al-Shatibi, although the preservation of the faculty of reason is part of the preservation of intellect (' $a q l$ ), it is also part of the objective of preservation of life in the sense that life needs to be preserved in order for human reason to be preserved. (Raysūnī and International Institute of Islamic Thought. 2005, 138) Hence the darūrī element of the maqasid of preserving the intellect is the prohibition of intoxicants, can be appended onto notions of health within al-Shatibi's framework. Converting these notions into a mental image, one can visualize a person with the essential aspects of health intact as a minimally-nourished, clothed individual, who has his procreative capacity intact and is free from the influence of intoxicants, and resides in a dwelling that protects him from the elements.

The two models overlap in deeming the provision of food, clothing, and shelter, and security from the influence of intoxicants to be the essential aspects of health and flourishing. This focus on social conditions is particularly notable given the increasing attention the social determinants of health are given today. Over the last few decades, researchers and thought leaders have identified that health inequities and healthcare disparities are, in part, due to social and economic factors that disadvantage some groups of people more so than others. These differences associate with health outcomes and require concerted effort to ameliorate. Hence research agendas are increasingly trying to identify the links between social and economic characteristics such as educational attainment, food insecurity, housing conditions, and health, and policy stakeholders and public health intervention specialists increasingly seek to translate the knowledge of social determinants into programs that improve community health. Those seeking to find "Islamic" grounds for social determinants of health might find fertile ground in these maqasid models.

The focus on procreation is missing in Attia's vision, while healthcare is not mentioned by al-Shataibi. One can explain the lack of focus on procreation in the essential means of the maqasid pertaining to the individual by Attia, by noting that the preservation of progeny is a maqasid at family level and procreation is deemed essential there. One might excuse the lack of focus on healthcare by alshatibiby suggesting that the benefit from medical practices in the $13^{\text {th }}$ century was not assured. However medical technology, healthcare professionals, and hospitals had made important contributions to society during al-Shataibìs lifetime, particularly in his home of Andalusia and in Muslim centers of learning in Baghdad, Damascus and Cairo. Nonetheless, the priority accorded to reproductive health in visions of flourishing is noteworthy and Muslim thinkers seeking to fashion an "Islamic" philosophy for healthcare, might consider the profound role reproductive health has to the maintenance of life from a maqasidi perspective.

The two models share much in common and affirm that Islamic law recognizes the importance of health. The minimalist visions presented demonstrate that food security, the provision of shelter and clothing, and penal repercussions for life-taking are necessary (ḍarūrī) for human existence and allow for a flourishing, and potentially religious, life. The base level of essential conditions needed to preserve human life, as defined by Islamic law, are built upon by the haji and tahsīnī elements. Once all are present, humanity would be able to live to its fullest potential in a universal sense. Those seeking to build a philosophy of public health and biomedicine from an Islamic perspective should take heed from hierarchical schema outlined in the maqasidi models so that the hajī and taḥsīnī elements are not focused on to the exclusion of the darūrī, because without a foundation no edifice can stand. Food security deserves more attention than the teaching of table manners, and outlawing murder is more important to human survival than providing for cosmetic surgery. Indeed maqasid models might prove useful in policy and program development. Yet, it is important to note that not only do the models presented here only describe the essential (darūrī ) aspects of preserving human life (and hence require building out for a more complete model), but that they might be dated. In other words contemporary knowledge about social and health conditions and policies can inform the classification of means (at least according to Attia) for preserving human life (and thereby securing health) into darūrī̄, hajī and tạ̣sīn̄i. And according to al-shatibi these data can provide insight into the human benefits and harms that are secondary objectives carried with the maqașid of preserving life. Consequently interdisciplinary efforts are needed to more fully develop visions of human health and well-being based on the frameworks and initial conceptions presented by these authors.

\section{Concluding Remarks on the applicability of the Maqasid to Biomedicine}

In closing, I would like to share a few thoughts on the amenability of maqasid frameworks for furnishing an "Islamic" philosophy and ethical framework for biomedicine. The theories of the higher objectives of Islamic law aim to secure human interests pertaining to this life and the next and thereby seek to offer a holistic vision for human flourishing. As such, theories of the higher 
objectives of the Lawgiver that are derived by an extensive examination of all scriptural sources and ordinances of the law, must comprehensively catalog and account for universal human interests. Consequently, the genre of maqasid should provide, at least theoretically, the foundations for developing comprehensive ethico-legal frameworks and furnish theological constructs that can inform philosophies.

Moving from theory to the practice, maqasid frameworks, as evidenced by our discussion of alshatibi and Attia's models, are relatively open systems and thus are adaptable to place, context, and changes in human understanding. In our preceding discussion we noted how al-shatibi gave epistemic authority to human reason in determining maqasid of the Lawgiver in many ways. From using ta'lil methods to identify objectives and wisdoms behind scripture-based commands, to identifying secondary objectives that are carried along with the text although not found within them, to using mașlahah mursalah to determine human benefits that become incorporated in the maqasid. Furthermore, for both al-shatibi and Attia, the principal method of arriving at the maqasid, induction, relies upon human reasoning. Attia similarly gives wide berth to reason in determining the means by which the maqasid are achieved as he resorts to using objective criteria to weigh the harms and benefits of different means. In obvious fashion empirical, social scientific and other data help inform human reasoning and thus "worldly" knowledge finds a role in informing scripturallyrooted maqasid by helping to determine what they are and how they might be achieved. These elements of maqasidi approaches make them particularly useful in bridging between the inherited legal canon and modern contexts and in giving them an enduring quality.

Yet at the same time, some of the limitations of the maqasid genre must be noted. For one, the field remains in its infancy as theoretical approaches and methods abound and practical tests of the theories remain limited. Theories and methods often develop as they are applied, and in general the many maqasid authors have yet to apply their theories to develop a comprehensive philosophy or ethics for a specific area of concern. As such, the various theories might yet be of limited utility. Additionally, the theoretical concepts might not be fleshed out in sufficient detail so as to afford the construction of a philosophy. Indeed, as evidenced above, the relative value of different aspects of health embedded within various maqasid approaches requires greater research into the components of the theories as well as conceptual development within them.

Related to the theoretical development is the matter of critical indeterminacies and ambiguities within specific theoretical models. As we noted above, the hierarchical ordering for the essential maqasid remains somewhat unclear within al-
Shataibi's model, and the field in general has yet to develop consensus around whether the preservation of religion is privileged over the preservation of life. These indeterminacies restrict application of the models to analyze "old" and to generate "new" Islamic laws. Furthermore, maqasid-based principalism for ethical decision-making cannot proceed without clarity on hierarchical structures and adjudication mechanisms when the higher objectives conflict.

In closing, the maqasid al-shariah represents a valuable means to bring Islamic ethico-legal values into conversation with modernity but more research and development must precede application.

\section{REFERENCES}

1. Raysūnī, Ahrmad. Imam al-Shatibi's theory of the higher objectives and intents of Islamic law. London ; Washington: International Institute of Islamic Thought. 2005.

2. Ibn Ashur, Muhammad Al-Tahir. Ibn Ashur: Treatise on Maqasid al-Shari 'ah. Translated by Mohamed El-Tahir El-Mesawi. London: International Institute of Islamic Thought, 2006.

3. Attia, Gamal Eldin. Towards Realization of the Higher Intents of Islamic Law. Translated by Nancy Roberts. London: The International Institute of Islamic Thought, 2007.

4. Auda, Jasser. Maqasid Al-Shariah: A Beginner's Guide. London,: The International Institute of Islamic Thought, 2008b.

5. Kamali, Mohammad Hashim. Maqāșid alSharī'ah, ljtihad and Civilisational Renewal. Edited by Dr. Anal s. Al Shaikh-Ali and Shiraz Khan, Occasional Papers Series: The International Institute of Islamic Thought and the International Institute of Advanced Islamic Studies, 2012.

6. Abdur-Rashid, K., S. W. Furber, and T. AbdulBasser. "Lifting the veil: a typological survey of the methodological features of Islamic ethical reasoning on biomedical issues." Theor Med Bioeth 2013; 34:81-93.

7. Auda, Jasser. Maqasid al-Shariah as Philosophy of Islamic Law: A Systems Approach. London: The International Institute of Islamic Thought, 2008a.

8. Nyazee, Imran A. K. Theories of Islamic Law. Islamabad, Pakistan: Islamic Research Institute and the International Institute of Islamic Thought, 2005.

9. Shataibī, Ibrahīm ibn Mūsá, Imran Ahsan Khan Nyazee, Raji M. Rammuny. The reconciliation of the fundamentals of Islamic law. 1st ed, Reading, UK: Garnet Pub, 2011. 